\section{KEBEBASAN DAN TANGGUNG JAWAB PERS DITINJAU DARI UNDANG-UNDANG NOMOR 40 TAHUN 1999 TENTANG PERS ${ }^{1}$ \\ Oleh: Theresia Romaito Sihombing ${ }^{2}$}

\begin{abstract}
ABSTRAK
Tujuan dilakukannya penelitian ini adalah untuk mengetahui bagaimana pelaksanaan fungsi kebebasan pers di Indonesia dan bagaimana tanggung jawab pers menuut Undang-Undang Nomor 40 Tahun 1999 tentang Pers. Dengan menggunakan metode peneltian yuridis normatif, disimpulkan: 1. Fungsi Kebebasan Pers di Indonesia untuk memberikan ruang gerak kepada masyarakat pers dalam berekspresi dan mengeluarkan pendapat. Dalam pelaksanaannya pers diharapkan menjalankan fungsi dan perannya secara bertanggung jawab. Fungsi pers Nasional yaitu sebagai media informasi, pendidikan dan edukasi, hiburan dan kontrol sosial kepada masyarakat. Kebebasan Pers dalam melaksanakan fungsi dan peranya pun dibatasi dengan Undang-Undang Nomor 40 Tahun 1999 tentang Pers dan Kode Etik Jurnalistik sebagai pedomannya. 2. Pers Naional bertanggung jawab kepada hukum dan perundang-undangan negara, dan berkewajiban memberikan peristiwa dan opini dengan menghormati norma-norma agama dan rasa kesusilaan masyarakat serta asas praduga tak bersalah. Pelanggaran norma ini dapat dikenakan sanksi pidana sebagaimana diatur dalam Pasal 18 Undang-Undang Nomor 40 Tahun 1999 tentang Pers. Apabila terdapat permasalahanpermasalahan akibat pemberitaan pers dalam interaksinya dengan masyarakat, maka penyelesaiannya harus diselesaikan melalui pemberitaan pula, yakni melalui hak jawab dan hak koreksi.

Kata kunci: Kebebasan dan Tanggung Jawab Pers, Ditinjau Dari Undang-Undang Nomor 40 Tahun 1999 tentang Pers
\end{abstract}

\section{PENDAHULUAN}

\section{A. Latar Belakang}

Kebebasan pers semenjak reformasi bergulir telah meninggalkan efek, baik positif maupun

\footnotetext{
${ }^{1}$ Artikel Skripsi. Dosen Pembimbing: Dr. Rudy H. Walukow, SH., MH; Ollij Aneke Kereh, SH., MH

2 Mahasiswa pada Fakultas Hukum Unsrat, NIM. 16071101011
}

negatif dalam masyarakat. Dampak positifnya yakni yang tengah dirasakan masyarakat saat ini dipermudah dalam memperoleh informasi apapun yang diinginkan. Kemudian fenomena saat ini pers berkembang bahkan bereuforia dengan kebebasannya. Kebebasan pers dalam mencari, mengolah sampai menyebarluaskan informasi ke masyarakat, telah menjadikan pers sebagai pilar penting dalam demokrasi. Akan tetapi, usai kemerdekaan pers memperoleh ruang gerak sebebas-bebasnya kemudian timbul keprihatinan masyarakat yang menilai bahwa kebebasan pers telah mengundang berbagai akses negatif akibat jurnalisme politik pers itu sendiri, yang oleh sebagian masyarakat cenderung ditafisirkan kebablasan. Pers seakan "lepas kendali" karena sering kebablasan dalam memposisikan peran strategisnya sebagai lembaga sosial kontrol sehingga memunculkan dua stigma yakni kebebasan pers atau kebablasan pers.

Untuk dapat keluar dari kondisi yang dilematis ini masyarakat pers perlu mengkondisikan diri dalam memanfaatkan kebebasannya secara bertanggung jawab, dan melaksanakan fungsinya sebagai salah satu pilar demokrasi.

Yang perlu diperhatikan, Pers mempunyai 3 (tiga) kewajiban, yaitu menjunjung tinggi kebenaran, menghormati privasi orang atau subyek tertentu, dan menjunjung tinggi prinsip bahwa apa yang diwartakan atau diberitakan dapat dipertanggungjawabkan. UndangUndang Pers yang merupakan produk hukum yang dimaksudkan untuk memberi kebebasan kepada pers agar lebih leluasa menjalankan peran dan fungsinya. Jadi, yang menjadi garis besar dalam hal ini yaitu, kebebasan pers bukanlah kebebasan yang seenaknya, melainkan kebebasan yang bertanggung jawab. Pers harus dapat menjalankan fungsi kontrol sosialnya secara bebas dan bertanggung jawab dengan berpedoman kepada ketentuan yang berlaku, dan menjunjung tinggi supremasi hukum $^{3}$. Dengan kebebasan pers yang tepat dan terukur, diharapkan agar seluruh penyelenggaraan pemerintahan dan demokrasi dapat dikontrol supaya tetap berjalan pada "jalan yang lurus dan benar". ${ }^{4}$

3 H. Syafriadi, Hukum Pers dalam Ketatanegaraan Indonesia, Suluh Media, Yogyakarta, 2018, hlm. 5.

${ }^{4}$ Ibid., hlm. 1. 
Dengan demikian berdasarkan uraian latar belakang, maka penulis hendak membahas dengan saksama yang hasilnya dituangkan dalam bentuk skripsi dengan judul "Kebebasan dan Tanggung Jawab Pers ditinjau dari UndangUndang Nomor 40 Tahun 1999 tentang Pers".

\section{B. Rumusan Masalah}

1. Bagaimana pelaksanaan fungsi kebebasan pers di Indonesia?

2. Bagaimana tanggung jawab pers menuut Undang-Undang Nomor 40 Tahun 1999 tentang Pers?

\section{Metode Penelitian}

Metode penelitian yang digunakan dalam penelitian ini yaitu metode penelitian yuridis normatif, dimana penelitian ini difokuskan untuk mengkaji penerapan kaidah-kaidah atau norma-norma dalam hukum positif.$^{5}$

\section{PEMBAHASAN}

\section{A. Pelaksanaan Fungsi Kebebasan Pers di Indonesia}

Mengenai nilai-nilai kebebasan pers sendiri, hal tersebut telah diakomodir dalam UndangUndang Dasar Negara Republik Indonesia Tahun 1945 yang telah diamandemen, yaitu diatur dalam Pasal 28, Pasal 28 E Ayat (2) dan (3) serta Pasal 28 F. $^{6}$ Pembatasan atas kemerdekaan menyampaikan pikiran, baik secara tulisan maupun tulisan, diatur dalam Pasal $28 \mathrm{~J}$ yang menyatakan sebagai berikut: ${ }^{7}$

1) Setiap orang wajib menghormati hak asasi manusia orang lain dalam tertib kehidupan bermasyarakat, berbangsa, dan bernegara.

2) Dalam menjalankan hak dan kebebasannya, setiap orang wajib tunduk kepada pembatasan yang ditetapkan dengan undang-undang dengan maksud semata-mata untuk menjamin pengakuan serta penghormatan atas hak dan kebebasan orang lain dan untuk memenuhi tuntutan yang adil sesuai dengan pertimbangan moral, nilai-nilai agama,

\footnotetext{
5 Johnny Ibrahim, Teori dan Metodologi Penelitian Hukum Normatif, Bayumedia Publishing, Malang, 2006, hlm. 295.

${ }^{6}$ Ibid.

${ }^{7}$ H. Syafriadi, op.cit., hlm. 145.
}

keamanan dan ketertiban umum dalam suatu masyarakat demokratis.

Pers yang bebas memberikan kontrol kepada pemerintah agar pemerintah tetap menjalankan tugasnya dengan baik, namun alangkah indahnya jika dalam melaksanakan tugasnya itu pers tetap professional dan berkembang. Pers yang bebas dan bertanggung jawab dalam masyarakat demokratis merupakan salah satu unsur bagi negara dan pemerintahan yang demokrasi. Posisi media dalam konteks demokrasi secara normatif dapat dilihat dari perundang-undangan mengenai pers, yaitu Undang-Undang Dasar Negara Republik Indonesia Tahun 1945 Pasal 28 F dan J, Undang-Undang Nomor 40 Tahun 1999 tentang Pers dan Undang-Undang Nomor 32 Tahun 2002 tentang Penyiaran.

Pada Pasal 5 Undang-Undang Nomor 32 Tahun 2002 tentang Penyiaran itu dikatakan bahwa Penyiaran diarahkan untuk: ${ }^{8}$

a. Menjunjung tinggi pelaksanaan Pancasila dan Undang-Undang Dasar Negara Republik Indonesia Tahun 1945;

b. Menjaga dan meningkatkan moralitas dan nilai-nilai agama serta jati diri bangsa;

c. Meningkatkan kualitas sumber daya manusia;

d. Menjaga dan mempererat persatuan dan kesatuan bangsa;

e. Meningkatkan kesadaran ketaatan hukum dan disiplin nasional;

f. Menyalurkan pendapat umum serta mendorong peran aktif masyarakat dalam pembangunan nasional dan daerah serta melestarikan lingkungan hidup;

g. Mencegah monopoli kepemilikan dan mendukung persaingan yang sehat di bidang penyiaran;

h. Mendorong peningkatan kemampuan perekonomian rakyat, mewujudkan pemerataan, dan memperkuat daya saing bangsa dalam era globalisasi;

i. Memberikan informasi yang benar, seimbang, dan bertanggung jawab;

j. Memajukan kebudayaan nasional.

8 Ibid, hlm. 146. 
Kebebasan pers tidak pernah berarti kebebasan tanpa kontrol. Negara Demokratis lazim memiliki batasan-batasan. Setidaknya ada enam hal yang perlu dibatasi dalam kebebasan pers yaitu: ${ }^{9}$

a) Menyebarkan kebencian;

b) Konten pencabulan dan pornografi;

c) Melakukan fitnah dan pencemaran nama baik;

d) Iklan yang berbohong (deceptive advertising);

e) Promosi zat yang tidak layak dikonsumsi anak dan remaja (misalnya rokok);

f) Pembocoran rahasia negara yang dapat membahayakan keselamatan negara.

Oleh karena itu, kebebasan pers perlu memberikan pembatasan-pembatasan paling tidak melalui rambu hukum, sehingga pemberitaan yang dilakukan oleh pers, dapat menjadi pemberitaan pers yang bertanggung jawab. Jadi pidana juga tetap diberlakukan terhadap pelaku yang dengan sengaja melakukan penghinaan atau fitnah dengan menggunakan pemberitaan pers sebagai media. Sementara, kebebasan pers untuk melakukan pemberitaan jika memang dilakukan secara bertanggung jawab dan professional, meskipun ada kesalahan dalam fakta pemberitaan tetap tidak boleh dipidana.

Dewan Pers merupakan sebuah lembaga independen yang berfungsi mengembangkan kemerdekaan pers dan meningkatkan kehidupan pers nasional. Dalam Pasal 15 Ayat (2) Undang-Undang Nomor 40 Tahun 1999 dikatakan bahwa fungsi Dewan Pers ${ }^{10}$ adalah sebagai berikut:
a. Melakukan pengkajian untuk pengembangan kehidupan pers;
b. Menetapkan dan mengawasi pelaksanaan Kode Etik Jurnalistik;
c. Memberikn pertimbangan dan mengupayakan penyelesaian pengaduan masyarakat atas kasus-kasus yang berhubungan dengan pemberitaan pers;
d. Mengembangkan komunikasi antara pers, masyarakat, dan pemerintah;
e. Memfasilitasi organisasi-organisasi pers dalam menyusun peraturan-peraturan di

\footnotetext{
9 Ibid, hlm. 147.

10 Lukas Warsito, Samsuri, Eriyanto, Sugeng Suprayanto, Harutjahjo Soewardojo, Mengelola Kebebasan Pers, Dewan Pers, Jakarta, 2008, hlm. 95.
}

bidang pers dan meningkatkan kualitas profesi kewartawanan;

f. Mendata perusahaan pers.

Dewan Pers, dalam meneliti dan menguji kualitas karya jurnalistik mengacu kepada sebelas butir Kode Etik Jurnalistik, dan penafsirannya sebagai alat analisis atas pelanggaran etika yang terjadi. Sebelas butir Kode Etik Jurnalistik menegaskan bahwa wartawan Indonesia: ${ }^{11}$

1) Bersikap independen, menghasilkan berita yang akurat, berimabng dan tidak beritikad buruk.

2) Menempuh cara-cara yang professional dalam melaksanakan tugas jurnalistik.

3) Selalu menguji informasi, memberitakan secara berimabng, tidak mencampurkan fakta dan opini yang menghakimi, serta menerapkan asas praduga tak bersalah.

4) Tidak membuat berita bohong, fitnah, sadis dan cabul.

5) Tidak menyebutkan dan menyiarkan identitas korban kejahatan susila dan tidak menyebutkan identitas anak yang menjadi pelaku kejahatan.

6) Tidak menyelahgunakan profesi dan tidak menerima suap.

7) Memiliki hak tolak untuk melindungi narasumber yang tidak bersedia diketahui identitas maupun keberadaannya, menghargai ketentuan embargo, informasi latar belakang, dan off the record sesuai dengan kesepakatan.

8) Tidak menulis atau menyiarkan berita berdasarkan prasangka atau diskriminasi terhadap seseorang atas dasar perbedaan suku, ras, warna kulit, agama, jenis kelamin dan bahasa serta tidak merendahkan martabat orang lemah, miskin, sakit, cacat jiwa. Atau cacat jasmani.

9) Menghormati hak narasumber tentang kehidupan pribadinya, kecuali untuk kepentingan public.

10) Segera mencabut, meralat dan memperbaiki berita yang keliru, dan tidak akurat disertai dengan permintaan

${ }^{11}$ H. Syafriadi, op.cit., hlm.160-161 
maaf kepada pembaca, pendengar atau pemirsa.

11) Melayani hak jawab dan hak koreksi secara proporsional.

Berdasarkan butir-butir Kode Etik Jurnalistik di atas, Dewan Pers mengidentifikasi kesalahan atau pelanggaran kode etik yang terjadi, dengan menilai itikad penyeberan informasi, cara membperoleh informasi, pengujian terhadap sumber informasi, serta penyampaiannya (tidak berprasangka, tidak diskriminatif, tidak menghakimi, tidak memfitnah, tidak merendahkan martabat, dan selalu menghormati privasi). Kesebelas butir tersebut menjadi pedoman bagi Dewan Pers dalam menilai, menelaah dan manganalsisis pengaduan masyarakat yang masuk ke Dewan Pers terutama yang terkait dengan karya Jurnalistik.

\section{B. Tanggung jawab Pers Menurut Undang- Undang Nomor 40 Tahun 1999 tentang Pers} Tanggung jawab menurut Kamus Besar Bahasa Indonesia, tanggung jawab memiliki arti keadaan wajib menanggung segala sesuatunya (kalau terjadi apa-apa boleh dituntut, dipersalahkan, diperkarakan, dan lain sebagainya), dapat juga diartikan dengan "hak fungsi menerima pembebanan sebagai akibat sikap sendiri atau pihak lain"12 Tanggung jawab merupakan kemampuan menerima atau memikul tanggung jawab yang timbul dari kesadaran dan kemauan sendiri atau akibat yang semata-mata karena perbuatan sendiri. Bertanggung jawab berarti kemampuan menerima atau memikul hak dan kewajiban atas dasar kebebasan (free will), bukan yang timbul karena suatu tekanan, atau keterpaksaan atau ketidakberdayaan. Kebebasan dengan pembatasan inilah yang kemudian disebut dengan tanggung jawab demokratik.

Alex Sobur berpendapat, tanggung jawab hanya dapat dikenakan kepada manusia, dan bukan kepada hewan. Dalam hal yang dimaksud dengan manusia adalah sudah dapat dikenai hukum. Anak kecil tidak atau belum dapat dikatakan bertanggung jawab atas "pelanggaran" yang dilakukannya. Andai kata anak kecil sewaktu bermain-main, lalu

\footnotetext{
12 Departemen Pendidikan Nasional, Kamus Besar Bahasa
} Indonesia, Balai Pustaka, Jakarta, 2007, hl. 1139. membakar rumah "orang" anak tersebut tidak akan dituntut oleh hukum.

Orang-orang pun tidak akan menganggap anak itu bersalah karena, pada dasarnya anak kecil belum mengerti apa yang dilakukannya. Karena itu disebut tanggung jawab adalah karena orang mengerti perbuatannya. ${ }^{13}$

Dalam sebuah norma hukum, terdapat dua elemen perilaku manusia yang dapat dibedakan antara kewajiban dan hak. Kedua norma tersebut tidak lengkap, dan membutuhkan norma lain untuk melengkapinya, yakni tanggung jawab individual atas perilaku yang diatur. Semua tindakan legal person adalah tindakan manusia yang bertanggung jawab yang membayangkan kesatuan hukum.

Tanggung jawab pers tidak dapat dipisahkan dari kebebasan pers yang sekarang dinikmati oleh pers. Kebebasan tidak mungkin disertai tanpa tanggung jawab, dan antara kebebasan dengan tanggung jawab merupakan dua mata rantai yang saling terkait. Dalam kehidupan bermasyarakat dan bernegara pun tidak ada kebebasan yang sifatnya mutlak. Kebebasan seseorang akan berhenti apabila melanggar kebebaan orang lain atau melanggar kepentingan umum. ${ }^{14}$ Begitu pun dengan wartawan, dalam pelaksanaan tugas-tugasnya terdapat hak dan tanggung jawabnya dalam hubungan dengan orang lain. Setiap orang bertindak tanpa tanggung jawab akan melemahkan tuntutan bagi kebebasan, dan untuk orang yang tidak memiliki kebebasan tidak mungkin padanya dituntut pertanggungjawaban. ${ }^{15}$

Untuk mendapatkan kebebasan atau kemerdekaan pers, harus mendukung dan menjunjung tinggi nilai-nilai demokrasi. Sehingga pers yang sehat merupakan pers yang merdeka yang menjalankan tugas jurnalistik secara benar, tepat, teratur dan tertib. ${ }^{16}$

Pers yang sehat memerlukan berbagai persyaratan. Berikut ini adalah empat syarat sehatnya sebuah pers.

1. Pers harus mengikuti sejumlah tuntutan dalam menjalankan profesi pers. Tuntutantuntutan tersebut adalah:

\footnotetext{
${ }^{13}$ Alex Sobur, op.cit., hlm. 318.

${ }^{14}$ H. Syafriadi, op.cit., hlm. 175.

$15 \mathrm{lbid}$.

16 Nynda Fatmawati Octarina, Pidana Pemberitaan Media Sosial, Setara Pers, Malang, 2018, hlm. 111.
} 
a. Tuntutan Etik

Tuntutan etik profesi bukan saja mengacu pada nilai moral tetapi juga mencakup tuntutan disiplin dan tanggung jawab. Tuntutan etik meliputi hal-hal seperti menjaga objektivitas, berimbang, tidak berpihak, kejujuran, cover both sides, berita semata-mata berdasarkan atas fakta, menjauhi kebohongan, menjauhi fitnah, menjauhi berita yang bersifat menekan, senantiasa menjunjung tinggi nilai-nilai kemanusiaan, baik terhadap subyek berita maupun orang-orang yang berkaitan dengan subyek berita, kerahasiaan narasumber dan lain-lain. ${ }^{17}$

b. Sopan Santun

Tuntutan etik akan sopan santun merupakan tuntutan tingkah lakusosial dan bersandar pada lingkungan atau tempat tertentu. Pers atau wartawan diharapkan dapat menghargai dan menghormati nilai-nilai dan tata karma yang berlaku atau dijunjung tinggi oleh orang-orang di wilayah tersebut. Menjaga sopan santun, tidak hanya memudahkan pelaksanaan tugas jurnalistik, tetapi dapat menghindari konflik atau sikap permusuhan yang akan menghambat pelaksanaan tugas jurnalistik. ${ }^{18}$

c. Tuntutan Hukum

Pers merupakan salah satu teladan masyarakat dalam hal kepatuhan terhadap hukum dan menjadi pendorong ketaatan pada hukum. Pers haruslah menjunjung tinggi hukum terutama hukum pers sehingga pers akan lebih mudah mendapatkan informasi tanpa harus berperkara karena melakukan tindakan melawan hukum.

d. Tuntutan Integritas

Integritas merupakan sikap dan ingkah laku untuk berbuat dengan cara-cara terbaik dan terhormat untuk menghasilkan yang terbaik. Integritas berhubungan erat dengan attitude dan character yang mencakup nilai-nilai

\footnotetext{
$17 \mathrm{lbid}, \mathrm{hlm} .112$.

18 Bagir Manan, Menuju Pers yang Bertanggung Jawab dan Sehat, Alumni, Bandung, 2010, hm. 6.
}

tanggung jawab, disiplin, kejujuran (fairness), dapat dipercaya atau amanah.

e. Tuntutan cita-cita

Wartawan atau pelaku pers harus memiliki dan bekerja keras atas dasar suatu cita-cita atau idealisme yang akan menjadi bintang pemandu kemajuan dan menjalankan tugas jurnalistik dengan baik sebagai pembawa informasi, pertukaran pikiran, dan berbagai tuntutan kemanusiaan atau sosial dalam suatu masyarakat demokratik.

2. Kompetensi dan profesionalisme

Setiap pekerjaan menuntut kompetensi yang tinggi yang meliputi kompetensi pengetahuan (knowledge), kompetensi keterampilan (skill), di samping tuntutan lain seperti kewajiban menjunjung tinggi etik, menjaga kepercayaan klienn, dan lain-lain. Selain sebagai syarat profesionalisme, masyarakat yang semakin maju dan kompleks disertai perkembangan ilmu dan teknologi menuntut informasi yang disebarkan oleh pers juga semakin berkembang menjadi lebih baik dan lebih mendetail dari sebelum-sebelumnya. ${ }^{19}$

3. Sistem Pengelolaan

Tujuan pengelolaan pers adalah untuk mencapai efisiensi, efektivitas, dan produktivitas sebagaimana fungsi dari perangkat-perangkat manajemen pada umumnya, pengelolaan (perusahaan dan penerbitan) pers yang baik, membangun dan memelihara kepercayaan publik.

4. Penuntun Masyarakat

Pers merupakan pranata atau lembaga sosial, pers milik publik, informasi publik seperti yang tertuang dalam UndangUndang Nomor 40 Tahun 1999 tentang Pers, "pers adalah lembaga sosial, pers wahana komunikasi massa". Hal ini bertujuan untuk menunjukkan tali ikatan antara pers dan masyarakat yakni pers seharusnya menjadi pekerja masyarakat, bekerja untuk kepentingan masyarakat dan bertanggung jawab pada masyarakat. Selain bertugass untuk memberikan informasi yang benar, pers yang bertanggung jawab dan sehat bertugas untuk menjadi penuntun masyarakat menuju ke situasi dan kondisi

$19 \mathrm{lbid}, \mathrm{hlm} .7-8$. 
yang tenteram dan lebih kondusif, menuju cita-cita bangsa yaitu mewujudkan kesejahteraan umum, mencerdaskan kehidupan bangsa, mencapai sebesarbesarnya kemakmuran rakyat atas dasar keadilan sosial bagi seluruh rakyat. ${ }^{20}$

Konsep tanggung jawab media atau media responsibility selalu digandengkan dengan sosial sehingga menjadi social responsibility media, khususnya yang telah melahirkan empat sistem pers Four Theories of the Press yang dikembangkan Siebert, Peterson dan Schramm. Keempat teori tersebut adalah; authoritarian theory, libertarian theory, social responsibility theory, dan Soviet-totalitarian theory. Social responsibility atau teori pers Bertanggung jawab sosial dijabarkan berdasarkan asumsi bahwa prinsip-prinsip teori pers libertarian terlalu menyederhanakan persoalan.

Dalam konteks Indonesia, pers bertanggung jawab kepada hukum dan perundang-undangan negara, bukan kepada pemerintah. ${ }^{21}$ Sebagai pedoman pelaksanaan kebebasan pers, dalam penjelasan Undang-Undang Nomor 40 Tahun 1999, Pasal 4 Ayat (1) ditegaskan, bahwa kemerdekaan pers adalah kemerdekaan yang disertai kesadaran pentingnya penegakan supremasi hukum yang dilaksanakan oleh pengadilan, dan tanggung jawab profesi yang dijabarkan dalam Kode Etik Jurnalistik sesuai dengan hati nurani insan pers. ${ }^{22}$ Pasal 2 Kode Etik Jurnalistik juga menegaskan, bahwa wartawan Indonesia dengan penuh rasa tanggung jawab dan bijaksana mempertimbangkan patut tidaknya menyiarkan berita tulisan, atau gambar, yang dapat membahayakan keselamatan dan keamanan negara, persatuan dan kesatuan bangsa, menyinggung perasaan agama, kepercayaan atau keyakinan suatu golongan yang dilindungi oleh undang-undang.

Pers nasional berkewajiban memberikan peristiwa dan opini dengan menghormati norma-norma agama dan rasa kesusilaan masyarakat serta asas praduga tak bersalah. ${ }^{23}$ Pelanggaran norma ini dapat dikenakan sanksi pidana sebagaimana diatur dalam Pasal 18

\footnotetext{
$20 \mathrm{lbid}, \mathrm{hlm} .10-11$.

${ }^{21} \mathrm{lbid}, \mathrm{hlm} .180$.

22 lbid.

23 Pasal 5 Undang-Undang Nomor 40 Tahun 1999.
}

Undang-Undang Nomor 40 Tahun 1999 tentang Pers sebagai berikut:

1) Setiap orang yang secara melawan hukum dengan sengaja melakukan tindakan yang berakibat menghambat atau menghalangi pelaksanaan ketentuan Pasal 4 Ayat (2) dan Ayat (3) dipidana dengan pidana penjara paling lama 2 (dua) tahun atau denda paling banyak Rp. 500.000.000,00 (lima ratus juta rupiah)

2) Perusahaan pers yang melanggar ketentuan Pasal 5 Ayat (1) dan Ayat (2), serta Pasal 13 dipidana dengan pidana denda paling banyak Rp. 500.000.000,00 (lima ratus juta rupiah)

3) Perusahaan pers yang melanggar ketentuan Pasal 9 Ayat (2) dan Pasal 12 dipidana dengan pidana denda paling banyak Rp. 100.000.000,00 (seratus juta rupiah).

Pers yang merdeka dan bebas merupakan salah satu pilar demokrasi dan menjadi prasyarat penting dalam membentuk dan menuju good governance untuk Indonesia. Itulah sebabnya Undang-Undang Nomor 40 Tahun 1999 tentang Pers khususnya konsideran menimbang butir $\mathrm{c}$ dengan tegas merumuskan bahwa:

“Pers Nasional sebagai wahana komunikasi massa, penyebar informasi dan pembentuk opini harus dapat melaksanakan asas. Fungsi, hak, kewajiban dan peranannya dengan berdasarkan kemerdekaan pers yang professional sehingga harus mendapat jaminan dan perlindungan hukum, serta bebas dari campur tangan dan paksaan dari manapun".

Bahkan dalam rangka memberikan jaminan itu, Pasal 4 Ayat (2) Undang-Undang Nomor 40 Tahun 1999 tentang Pers, menyatakan terhadap Pers nasional tidak dikenakan penyensoran, pembredelan atau pelarangan penyiaran.

Apabila dalam melaksanakan peran dan fungsinya terdapat permasalahanpermasalahan akibat pemberitaan pers dalam interaksinya dengan masyarakat, maka penyelesaiannya harus diselesaikan melalui pemberitaan pula, yakni melalui hak jawab dan 
hak koreksi. ${ }^{24}$ Hak jawab adalah hak seseorang atau sekelompok orang untuk memberikan tanggapan atau sanggahan terhadap pemberitaan berupa fakta yang merugikan nama baiknya. Hak koreksi adalah hak setiap orang untuk mengoreksi atau membetulkan kekeliruan informasi yang diberitakan oleh pers, baik tentang dirinya maupun tentang orang lain.

Pemuatan hak jawab dan hak koreksi merupakan bentuk tanggung jawab sosial pers kepada masyarakat dalam penyajian informasi yang merugikan narasumber dan masyarakat. Tanggung jawab yang dimaksud adalah hasil akhir dari pola aktivitas yang dilaksanakan oleh pers mulai dari aktivitas yang bersifat individual dari para wartawan sampai kepada penyampaian informasi sebagai sebuah produk yang membawa muatan institusional. ${ }^{25}$ Tindak lanjut dari Pasal 6 Undang-Undang Nomor 40 Tahun 1999 tersebut, Dewan Pers menerbitkan Keputusan Dewan Pers Nomor 79/XIV/1974 tertanggal 1 Desember 1974 tentang Peraturan Pelaksana Pembinaan Idiil Pers. Dalam keputusan itu, Dewan Pers memaparkan ilustrasi proses terjadinya sebuah berita hingga akhirnya berita tesebut dapat dibaca oleh khalayak. Penggarisan ini dijadkan sebagai dasar kinerja pers, dan secara garis besar, berita-berita tersebut berproses melalui tahapan-tahapan tertentu, yakni: 1) Event peristiwa sampai ke reporter; 2) Reporter memeriksa apakah event itu benar-benar fact. Jika bukan fact dibuang dan jika fact naik ke tahap berikutnya; 3) Reporter menimbang apakah fact itu ada news value-nya. Apabila tidak dibuang dan apabila ada news value nya terus ke tahap IV; 4) Repoter menilai apakah fact yang ada news value nya itu fit to print. Apabila tidak, disimpan di arsip, apabila fit to print terus ke tahap V; 5) Tahp ini, fact yang ber-news value dan fit to print itu disusun untuk dimuat di surat kabar atau disiarkanoleh radio dan televisi; 6) Pada tahap ini fact bernews value fit to print yang sudah tersusun dicetak; 7) Pada tahap ini surat kabar didistribusikan, dan 8) pada tahap terakhir ini surat kabar sampai ke tangan pembaca maka secara teknis jurnalistik event sudah jadi news.

\footnotetext{
${ }^{24}$ H. Syafriadi, op.cit., hlm. 183.
}

25 Ibid.
Pertanggungjawaban yang terdapat dalam Undang-Undang Nomor 40 Tahun 1999 mengatakan bahwa pemimpin redaksi harus bertanggung jawab terhadap sajian pers. Samsul Wahidin berpandangan, jika dihubungkan dengan delapan tahapan proses penulisan berita sebagaimana dijelaskan di awal adalah pertanggungjawaban ketika sudah sampai ke tahap delapan atau event sudah menjadi berita. Pada tahap ini pertanggungjawaban sudah bersifat eksternal dalam membawa pengaruh secara luas pada masyarakat. Disini lah mulainya tanggung jawab hukum atas kajian pers. ${ }^{26}$

\section{PENUTUP}

\section{A. Kesimpulan}

1. Fungsi Kebebasan Pers di Indonesia untuk memberikan ruang gerak kepada masyarakat pers dalam berekspresi dan mengeluarkan pendapat. Dalam pelaksanaannya pers diharapkan menjalankan fungsi dan perannya secara bertanggung jawab. Fungsi pers Nasional yaitu sebagai media informasi, pendidikan dan edukasi, hiburan dan kontrol sosial kepada masyarakat. Kebebasan Pers dalam melaksanakan fungsi dan peranya pun dibatasi dengan Undang-Undang Nomor 40 Tahun 1999 tentang Pers dan Kode Etik Jurnalistik sebagai pedomannya.

2. Pers Naional bertanggung jawab kepada hukum dan perundang-undangan negara, dan berkewajiban memberikan peristiwa dan opini dengan menghormati normanorma agama dan rasa kesusilaan masyarakat serta asas praduga tak bersalah. Pelanggaran norma ini dapat dikenakan sanksi pidana sebagaimana diatur dalam Pasal 18 Undang-Undang Nomor 40 Tahun 1999 tentang Pers. Apabila terdapat permasalahanpermasalahan akibat pemberitaan pers dalam interaksinya dengan masyarakat, maka penyelesaiannya harus diselesaikan melalui pemberitaan pula, yakni melalui hak jawab dan hak koreksi.

\section{B. Saran}

${ }^{26}$ Samsul Wahidin, op.cit. hlm. 135. 
Peningkatan kualitas pers merupakan hal yang paling utama yang harus dilaksanakan, lembaga pers juga harus selalu menyempurnakan kinerjanya sehingga mampu menyampaikan informasi yang tepat, akurat dan benar kepada seluruh masyarakat. Dalam menyampaikan informasi, harus selalu melakukan penelitian ulang sebelum menyiarkannya, menggali informasi dan mengangkat berita secara berimbang

Sebagai satu-satunya undang-undang yang tidak ada Peraturan Pemerintah (PP) maupun Peraturan Menteri (Permen) sebagai peraturan pelaksananya. Diharapkan para wartawan professional dan masyarakat pers, dengan difasilitasi Dewan Pers, bisa mengatur diri sendiri melalui penyusunan berbagai peraturan, pedoman termasuk menyusun Kode Etik Jurnalistik. Sebuah hal yang lebih merupakan pengatuan pers oleh masyarakat pers sendiri atau sebuah self regulating.

\section{DAFTAR PUSTAKA}

BUKU:

Abdul Fatah, Hukum Pers Indonesia, Setara Press, Malang, 2019.

Alex Sobur, Etika Pers, Profesionalisme Dengan Nurani, Humaniora Utama Press, Bandung, 2001.

Ana Nadhya Abrar, Analisis Pers Teori dan Praktik, Cahaya Atma Pustaka, Yogyakarta, 2011.

Bagir Manan, Menuju Pers yang Bertanggung Jawab dan Sehat, Alumni, Bandung, 2010.

Edy Susanto, Mohammad Taufik Makarao dan Hamid Syamsudin, Hukum Pers di Indonesia, Rineka Cipta, Jakarta, 2010.

Edward C. Smith, Pembredelan Pers di Indonesia, Grafiti Pers, Cetakan kedua, Jakarta, 1986.

H. Syafriadi, Hukum Pers dalam Ketatanegaraan Indonesia, Suluh Media, Yogyakarta, 2018.

Jacob Oetama, Pers Indonesia Berkomunikasi dalam Masyarakat Tidak Tulus, Penerbit Buku Kompas, Jakarta, 2001.

Krisna Harahap, Pasang Surut Kemerdekaan Pers di Indonesia, PT. Grafitri, Bandung, 2003.
Lukas Luwarso, Mengatur Kebebasan Pers, Dewan Pers, Cetakan Pertama, Jakarta 2003.

Lukas Warsito, Samsuri, Eriyanto, Sugeng Suprayanto, Harutjahjo Soewardojo, Mengelola Kebebasan Pers, Dewan Pers, Jakarta, 2008.

M. Ridlo 'Eisy, Peranan Media Dalam Masyarakat, Kemerdekaan Pers Fondasi Penegakan Hak Asasi Manusia, Dewan Pers, Jakarta, 2007.

Nynda Fatmawati Octarina, Pidana Pemberitaan Media Sosial, Setara Pers, Malang, 2018.

Oemar Seno Adji, Mass Media dan Hukum, Erlangga, Jakarta, 1977.

Samsul Wahidin, Hukum Pers, Cetakan Pertama, Pustaka Pelajar, Yogyakarta, 2006.

Tri Buana Said, Sejarah Pers Nasional dan Perkembangannya, CV Mas Agung, Jakarta, 1988.

Unesco, Aneka Suara Satu Dunia, Balai Pustaka Jakarta, 1983.

\section{JURNAL \& TESIS:}

Bayu Hardiyudanto, Penerapan Hukum Pidana Terhadap Pemberitaan Pers Yang Dapat Memicu Konflik di Masyarakat, Tesis Magister Fakultas Hukum Program Pascasarjana, Universitas Indonesia, Jakarta, Juni 2011

Dewan Pers, Menunggu Wujud Nyata Kemerdekaan Pers, Jurnal Dewan Pers, Edisi 16, Jakarta, 2017

Satrio Saptohadi, Pasang surut kebebasan pers di Indonesia, Jurnal Dinamika Hukum, Vol.11 No. 1, Januari 2011, Purwokerto: Fakultas Hukum Universitas Jenderal Sudirman

\section{KAMUS}

Departemen Pendidikan dan Kebudayaan, Kamus Besar Bahasa Indonesia, Balai Pustaka, Jakarta, 1990.

Departemen Pendidikan Nasional, Kamus Besar Bahasa Indonesia, Balai Pustaka, Jakarta, 2007

\section{PERATURAN PERUNDANG-UNDANGAN}

Undang-Undang Dasar Negara Republik Indonesia Tahun 1945 
Undang-Undang Nomor 40 Tahun 1999 tentang Pers

Undang-Undang Nomor 11 Tahun 1966 tentang Ketentuan-Ketentuan Pokok Pers

Undang-Undang Nomor 32 Tahun 2002 tentang Penyiaran

Kode Etik Jurnalistik

Keputusan Dewan Pers Nomor 79/XIV/1974 tertanggal 1 Desember 1974 tentang Peraturan Pelaksana Pembinaan Idiil Pers

\section{MAKALAH \& WEBSITE:}

Felix Hart, "Bentuk Penyalahgunaan Kebebaan Pers" diakses dari https://www.academia.edu/8237841/B entuk_penyalahgunaan_kebebsan_ Pers, pada tanggal 27 November 2019, pukul 00.59 WITA

Mahfud Achyar, "Kebebasan Pers dan Demokrasi", diakses dari https://www.kompasiana.com/mahfud. achyar/kebebasan-pers-dandemokrasi, pada tanggal 25 November 2019 pukul 11.10 WITA

Merdeka.com, "2 contoh kasus pelanggaran kebebasan pers di Indonesia", diakses dari https://www.google.com/amp/s/m.me rdeka.com/amp/pendidikan/2-contohkasus-pelanggaran-kebebasan-pers-diindonesia.html, pada tanggal 26 November 2019, pukul 11.29 WITA

Rahmad Hidayat, "Bentuk-bentuk Penyalahgunaan Kebebasan Pers", diakses dari https://www.kitapunya.net/2015/12/b entuk-bentuk-penyalahgunaankebebasan-pers.html?m=1, pada tanggal 27 November 2019, pukul 01.25 WITA

Saidi Rifky, "Kebebasan Pers Ditinjau dari Segi Fungsi", diakses dari https://www.kompasiana.com/amp/sai dirifky/kebebasan-pers-ditinjau-darisegi-fungsi, pada tanggal 26 November 2019, pukul 22.05 WITA 